\title{
RELATIONSHIPS BETWEEN MAINSTREAM PARTICIPATION RATES AND ELITE SPORT SUCCESS IN DISABILITY SPORTS
}

\author{
Rinske de Jong, Bart Vanreusel*, Rita van Driel**
}

\author{
NOC ${ }^{*}$ NSF, Arnhem, Netherlands \\ *Katholieke Universiteit Leuven, Leuven, Belgium \\ ${ }^{* *}$ NOC ${ }^{*} N S F$, Arnhem, Netherlands
}

The purpose of this study was to determine relationships between participation rates in mainstream and elite sports for persons with a disability and the achieved elite sport success. Data on performances of Dutch athletes of 16 of the 2008 summer Paralympic sports in which the Netherlands were active and on mainstream participation of these 16 sports have been obtained by questionnaires and additional interviews. Spearman's correlation or Kendall's tau were used to analyse relationships in all Paralympic sports and in team and individual sports separately, while correcting for gender differences. It can be confirmed that a two-way relationship is partly present in disability sports; on the one hand there is a supply function from mainstream to elite sports, and on the other hand there is an inspirational function from elite to mainstream sports. However, these correlations were different between females and males and between team sports and individual sports. These findings are relevant for policy making towards an increase in participation rates in disability sports at a mainstream level and towards improving Paralympic success.

KEYWORDS: Participation rates, mainstream sports, elite sport success, disability sports, double pyramid theory, sport policy.

\section{INTRODUCTION}

A growing amount of literature confirms that people with a disability can benefit physically, mentally and socially from a physically active lifestyle as the general population does (Cooper, Quatrano \& Axelson, 1999; Durstine, Painter, Franklin, Morgan, Pitetti \& Roberts, 2000; Heath \& Fentem, 1997; Van der Ploeg, Van der Beek, Van der Woude \& Van Mechelen, 2004; Shephard, 1991). Being physically active positively influences their mobility, and can therefore reduce the effects of the disability and improve their quality of life (Durstine et al., 2000; Van der Ploeg et al., 2004). However, people with a disability are on average more inactive than the general population (Campen \& Schellingerhout, 2005; Heath \& Fentem, 1997; Kooiker \& Van Campen, 2006; Van Lindert, De Jong \& Van den Dool, 2008).
Many countries want to increase the participation in mainstream sports for the aforementioned beneficial reasons. Another rationale is to improve Paralympic success (VWS, 2005). It is widely believed that increased mainstream participation will have a positive effect on elite sport success and vice versa. This model is labelled as the 'double pyramid theory' (Van Bottenburg, 2002). In this popular theoretical model a two-way relationship is assumed between mainstream and elite sports; there is on the one hand a supply function from mainstream sports to elite sports, and on the other hand an inspirational function from elite sports to mainstream sports (Van Bottenburg, 2002; Van Bottenburg, 2003). In a research in 17 European countries a correlation of $r=0.535$ ( $p<0.01)$ was found between the number of sport participants active in an organised way and the ratio of medals per million inhabitants during the Olympic games of the period 19922000 (Van Bottenburg, 2002). When 
analysing the part of the population which engages in sports in an intensive, competitive or organised fashion, the correlation was found to be even higher $(r=0.789, p<0.05)$ in 7 European countries (Van Bottenburg, 2002).

Scientific evidence is lacking to support the inspirational function for elite sports in able-bodied sports. Elite success and accompanying role models did not always lead to an increase in participation rates in mainstream sports; the effect seemed to differ between sports (Van Bottenburg, 2002; Van Bottenburg, 2003; De Knop, De Bosscher, Van Bottenburg and Leblicq, 2006). For example, the European Championship of the Dutch soccer team in 1988 did not lead to an increase in club memberships, whereas an increase of hockey club members was shown after winning the Olympic gold medal in 1996 by the Dutch hockey team. An extra amount of media attention might explain this phenomenon partly (Van Bottenburg, 2002).

Research evidence about a two-way relationship in sports for people with a disability is lacking. Most research is based on able-bodied sports which does not verify that the findings apply to sports for persons with a disability. For example, disability sports officially started in 1948, whether ablebodied sports is known for centuries (Van Bottenburg, 2002; Gold, 2007). Unlike ablebodied sports, more disability sports opportunities exist for adults than for children (Steadward \& Wheeler, 1996). Furthermore, persons with a disability participate in other types of sports and the reasons to be actively involved in sports are different (Van Bottenburg, 2003; Van Lindert et al., 2008).

Therefore, generalisation of the two-way relationship towards disability sports cannot be reliably made. However, policy making institutions who want to increase the participation rates in disability sports at a mainstream level to improve the chance of Paralympic success do need this knowledge for accurate policy making. The aim of this study is therefore to determine relationships between participation rates in mainstream and elite sports for persons with a disability and the achieved elite success.

\section{METHOD}

\section{Design of the study}

This study focuses on the situation of disability sports in the Netherlands. Dutch athletes are active in almost all Paralympic summer sports and are relatively successful. Therefore, they can be considered as a valid sample. However, the Dutch government wants to raise the level of achievement of elite disabled talents and athletes at European Championships, World Championships and the Paralympics (VWS, 2008). To reach this goal, the Netherlands try to organise disability sports in an innovative way, which is another reason to focus on the Dutch situation in this study. The organisation of disability sports has changed towards a more integrated structure in the last years. Nowadays, only six sports are still under supervision of Gehandicaptensport Nederland (a Dutch federation for some disability sports which are not yet integrated). The other disciplines have been integrated in the individual sports federations which were the supervising organisations for able-bodied sports. Due to this complexity, we chose to design the study as a data based descriptive analysis.

\section{Survey instruments}

Data of the 2008 summer Paralympic games in which Dutch Paralympic athletes were active have been collected by questionnaires, as described below. Official websites of sports federations were consulted to collect further data on mainstream level disability sports. Representatives from NOC*NSF were interviewed to complete missing data on elite level disability sports. The official website of the Paralympic Games (www.paralympics.org) was consulted to check results achieved by the Dutch elite athletes of this study during the Paralympic games of 2008 .

\section{Questionnaire}

To collect data of different sports a questionnaire was created containing 
descriptive questions about participation rates on mainstream and elite level and elite sport success.

Sports federations were asked to count their female and male members with a physical disability on a mainstream level and an elite level. Van Bottenburg (2002) found no significant relationships between participation rates in mainstream sports and elite sport success when adopting a very broad definition of mainstream sports (the percentage of the population that participates in a sport more than once a year). Therefore only athletes active in an organised way were counted.

Results of the previous Paralympic Games were requested and double checked on the website of the Paralympic Games. The best 8 athletes in each discipline were scored using the following score system: $10-8-6-$ $5-4-3-2-1$ points. This method reduces the influence of one individual athlete winning multiple medals (Van Bottenburg, 2002). The total amount of points per sport represents the absolute success achieved in this sport. To make all data comparable, relative success was calculated by dividing the total points of each sport by the maximal amount of points which could have been achieved for each sport discipline by the Netherlands according to the International Paralympic Committee (IPC).

\section{Participants of the study}

The questionnaires were sent via NOC*NSF to the person with access to information in the 12 involved sports federations and Gehandicaptensport Nederland, in most cases the coordinators of sport for persons with a disability. Nonresponders were followed up by e-mail and telephone. No data was collected for archery and shooting. Therefore, only data on performances of Dutch athletes of the remaining 16 Paralympic summer sports in which the Netherlands were active in 2008 and on mainstream participation of these 16 sports, are used in the analysis. The final response rates per questionnaire item are summarised in table 1.

\section{Table 1}

Response rates of the 16 Paralympic summer sports in percentages on different items of the questionnaire

\begin{tabular}{lcc}
\hline Items & Response rates mainstream level & Response rates elite level \\
\hline Participation & $88 \%$ & $100 \%$ \\
Participation women & $44 \%$ & $94 \%$ \\
Participation men & $44 \%$ & $94 \%$ \\
Top sport success & Only elite success measured & $100 \%$ \\
Top sport success women & Only elite success measured & $100 \%$ \\
Top sport success men & Only elite success measured & $100 \%$
\end{tabular}

The response rates show that several Dutch sports federations had difficulties to deliver clear data on the situation of disability sports at a mainstream level. Therefore different sample sizes had to be used in the statistical analysis.

\section{Statistical analysis}

Data were analyzed using the Scientific Package of Social Sciences (SPSS) version
17.0. To examine differences between different sports disciplines, clusters were made to increase the sample size. Van Lindert et al. (2008) used the distinction in single sports, duo sports and team sports. However, this caused difficulties with rowing, sailing, table tennis and wheelchair tennis, where single as well as duo sports are present. Therefore, in this study we chose to divide the sports in only two groups; team sports and the 
other sports, further mentioned as individual

sports.

Table 2

Distinction of the 16 Paralympic summer sports in 11 individual sports and 5 team sports and an explanation of the different types of competition in which the sport is practised

\begin{tabular}{|c|c|}
\hline Individual sports & Types of competition \\
\hline Athletics & Male and female \\
\hline Boccia & Mixed sport \\
\hline Cycling & Male and female \\
\hline Equesrian & Mixed sport \\
\hline Judo & Male and female \\
\hline Powerlifting & Male and female \\
\hline Rowing & Male, female and mixed \\
\hline Sailing & Mixed sport \\
\hline Swimming & Male and female \\
\hline Table tennis & Male and female \\
\hline Wheelchair tennis & Male, female and mixed \\
\hline
\end{tabular}

\begin{tabular}{ll}
\hline Team sports & Types of competition \\
\hline Football 7-a-side & Male and female \\
Goalball & Male and female \\
Volleyball & Male and female \\
Wheelchair basketball & Male and female \\
Wheelchair rugby & Male and female
\end{tabular}

A Mann-Whitney test was calculated to investigate significant differences between these two sports categories. This procedure was also used to find significant gender differences in the sports where women and men have their own competitions (table 2). The non-parametric test is used because of the small sample sizes and the abence of a normal distribution as tested with the KolmogorovSmirnof test.

Spearman's correlation or Kendall's tau, in cases of 5 tied ranks or more, were calculated between participation rates at mainstream and elite level and achieved elite sport success. The same procedure was used to study correlations in female and male subsamples.

In all tests the $\mathrm{N}$ (amount of sports) needed to be at least 4 to meet reliability criteria. In all correlational tests, P-values lower than 0.05 (one-tailed tests) were considered to be statistically significant. For the Kolmogorov-Smirnov test a two- tailed significance was used.

\section{RESULTS}

Table 3 shows a high standard deviation in amount of mainstream participants, which means that some sports are more popular compared to others. However, a MannWhitney test did not result in significant differences in mainstream participation rates between the 5 Paralympic team sports and the 11 individual sports. Gender differences in mainstream participation were not found to be significant either.

No significant differences between Paralympic team sports and individual sports were shown in elite sports participation rates. Although mainstream sports participation was almost equal between women and men, male elite participation was almost double the female elite participation. Amounts of female and male elite participants did not significantly differ.

Female athletes were almost twice as successful as male athletes at the Paralympic Games of 2008, this difference was not found to be significant. The Dutch athletes achieved comparable relative success in individual and team sports. 
Figure 1. Correlations between mainstream- and elite participation rates and relative Paralympic success. $\mathrm{N}$ is the sample size and $*$ indicates $\mathrm{p}<0.05$.

a. Relationships in all Paralympic summer sports. b. Relationships for females in all Paralympic sports. c. Relationships for males in all Paralympic sports.

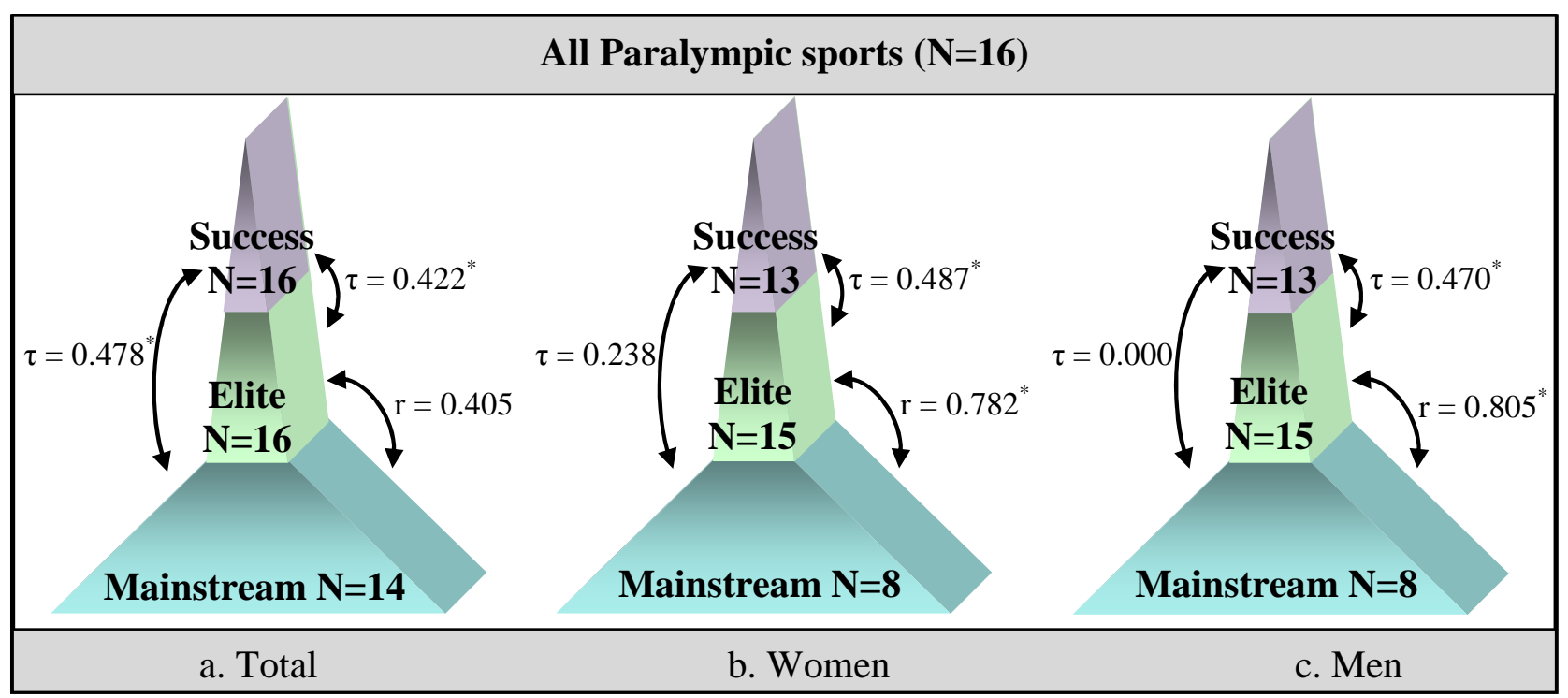

Figure 2. Correlations between mainstream- and elite participation rates and relative Paralympic success in the 11 individual sports. $\mathrm{N}$ is the sample size and $*$ indicates $\mathrm{p}<0.05$.

a. Relationships in all individual Paralympic sports. b. Relationships for females in the individual Paralympic sports. c. Relationships for males in the individual Paralympic sports.

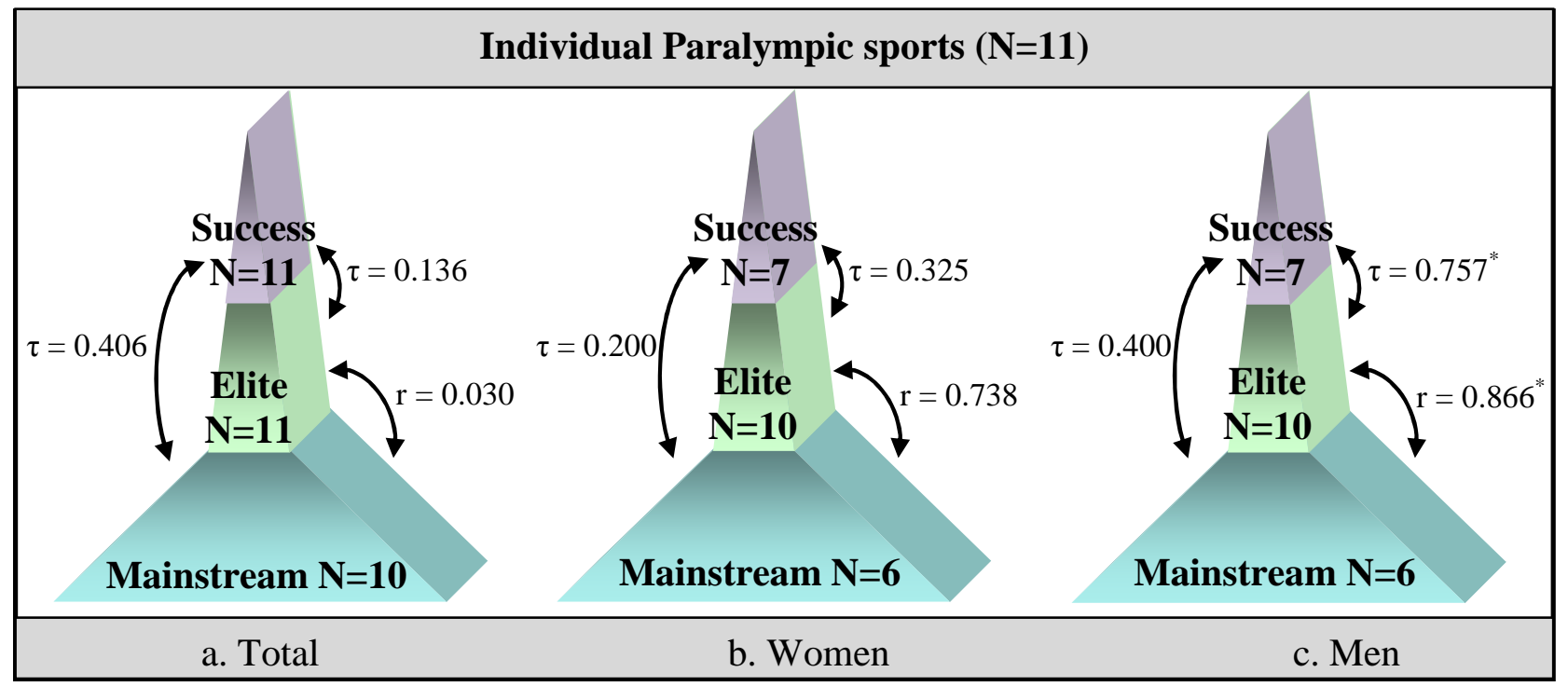


Figure 3. Correlations between mainstream- and elite participation rates and relative Paralympic success in the 5 team sports. $\mathrm{N}$ is the sample size, $*$ indicates $\mathrm{p}<0.05$ and $* * *$ indicates $\mathrm{p}<0.001$. $\mathrm{X}$ is used when the sample size is too small to calculate Spearman's test or Kendall's tau.

a. Relationships in all Paralympic team sports. b. Relationships for females in the Paralympic team sports. c. Relationships for males in the Paralympic team sports.

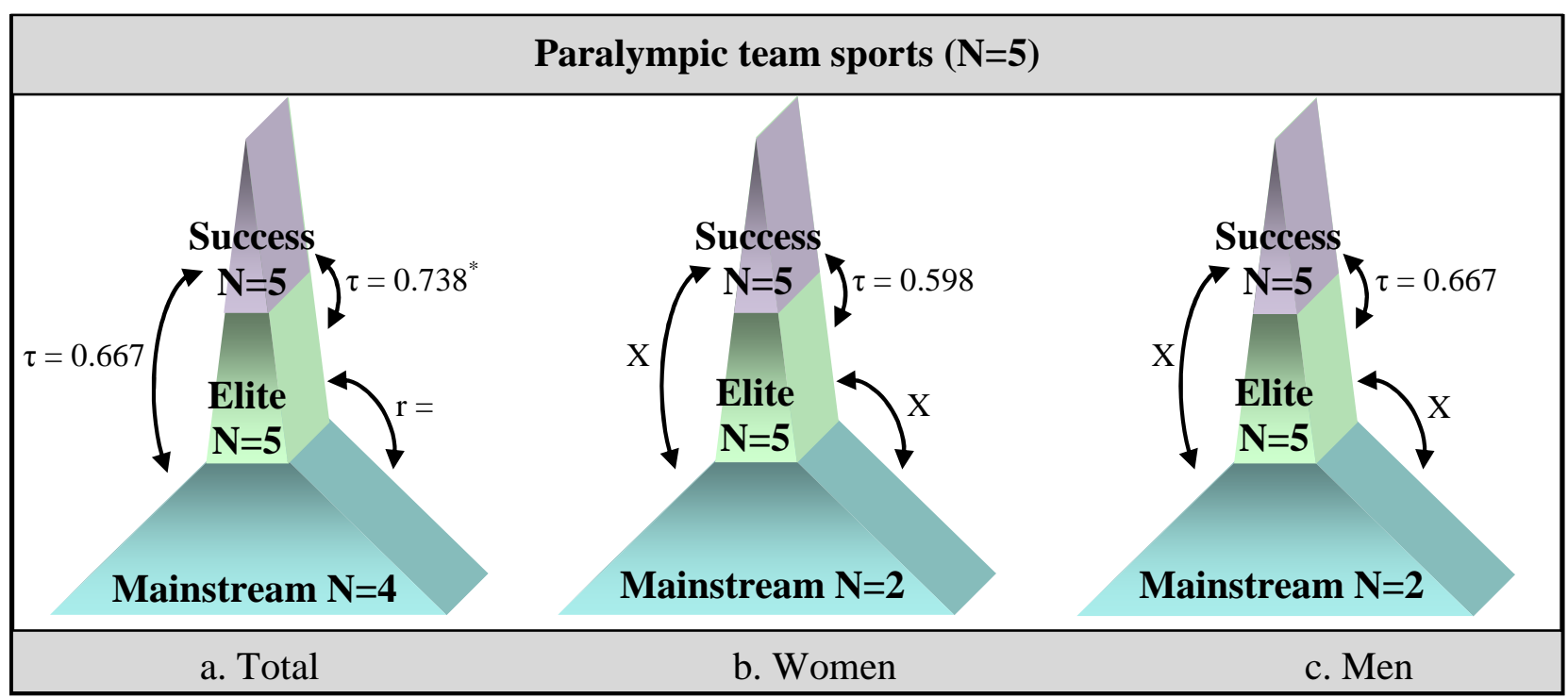

Correlations between amount of mainstream sports participants, elite participants and Paralympic success are given in figure 1, 2 and 3. No significant correlation was found between mainstream- and elite participation rates. However in the female population this correlations was shown to be $r$ $=0.782(\mathrm{p}$ (one-tailed) $<0.05$, figure $1 \mathrm{~b})$ whereas for the male population a correlation of $r=0.805(\mathrm{p}$ (one-tailed) $<0.05$, figure $1 \mathrm{c}$ ) was found. When team sports were analysed separately there was a large correlation between the amount of mainstream and elite sports participants $(\mathrm{r}=1.000, \mathrm{p}$ (one-tailed) < 0.001 , figure $3 \mathrm{a}$ ). For individual sports this correlation was not found at all (figure $2 a$ ).

In Dutch disability sports in general a significant correlation was shown between mainstream participation rates and achieved elite sport success ( $\tau=0.478, \mathrm{p}$ (one-tailed) < 0.05 , figure $1 \mathrm{a}$ ). A significant relationship was also found between the amount of elite participants and success $(\tau=0.422$, p (onetailed) $<0.05$, figure $1 \mathrm{a}$ ). This correlation was significant in the female as well as the male population (respectively $\tau=0.487$, $\mathrm{p}$ (onetailed) $<0.05$, figure $1 \mathrm{~b}$ and $\tau=0.470$, $\mathrm{p}$ (onetailed) $<0.05$, figure 1c). For team sports the correlation between elite sports participants and achieved elite sport success was $\tau=0.738$ ( $\mathrm{p}$ (one-tailed) $<0.05$, figure $3 \mathrm{a}$ ) while for the individual sports this relationship was not shown (figure 2a). However, the amount of male elite athletes of individual sports correlated with the male achieved success ( $\tau=$ 0.757, $\mathrm{p}$ (one-tailed) $<0.05$, figure $2 \mathrm{c}$ ).

\section{DISCUSSION}

In this study assumed relationships between the number of sports participants at a mainstream level, the number of sports participants at an elite level and Paralympic success were analysed. Gender differences were examined and team sports and individual sports were analysed separately to investigate differences between types of sports. To our knowledge research in this area was hardly done before.

In able-bodied sports a two-way relationship is assumed between mainstream and elite sport, the so-called 'double pyramid theory' (Van Bottenburg, 2002; Van Bottenburg, 2003). Because of the differences between able-bodied sports and sports for people with a disability, generalisation of the two-way relationship towards disability sports cannot be reliably made (Van Bottenburg, 
2002; Van Bottenburg, 2003; Gold, 2007; Van Lindert et al., 2008; Steadward \& Wheeler, 1996).

This study confirmed that the 'double pyramid theory' does only partly apply for disability sports as a whole. In a situation where all Paralympic sports were analysed (figure 1a) no significant correlation was found between mainstream and elite participation rates. However, when separately focusing on female and male participation, significant correlations were found of $\mathrm{r}=$ 0.782 for women and $r=0.805$ for men. Male elite participation was almost twice the amount of female elite participation, while mainstream participation was almost similar.

\section{Table 3}

Descriptive data of questionnaire items, $\mathrm{N}=$ amount of sports with available data, mean and standard deviation $(\mathrm{SD})$

\begin{tabular}{|c|c|c|c|c|c|c|c|c|c|}
\hline \multirow[b]{2}{*}{ Mainstream sport items } & \multicolumn{3}{|c|}{ Total sports } & \multicolumn{3}{|c|}{ Individual sports } & \multicolumn{3}{|c|}{ Team sports } \\
\hline & $\mathbf{N}$ & Mean & SD & $\mathbf{N}$ & Mean & SD & $\mathbf{N}$ & Mean & SD \\
\hline Total participants & 14 & 423.64 & 647.45 & 10 & 281.80 & 354.74 & 4 & 778.25 & 1097.37 \\
\hline Female participants & 8 & 88.63 & 116.04 & 6 & 53.00 & 56.67 & 2 & 195.50 & 218.50 \\
\hline Male participants & 8 & 101.25 & 86.40 & 6 & 93.00 & 99.46 & 2 & 126.00 & 33.94 \\
\hline Elite sport items & $\mathbf{N}$ & Mean & SD & $\mathbf{N}$ & Mean & SD & $\mathbf{N}$ & Mean & SD \\
\hline Total participants & 16 & 16.00 & 14.97 & 11 & 11.00 & 8.29 & 5 & 27.00 & 21.17 \\
\hline Female participants & 15 & 4.93 & 5.64 & 10 & 3.60 & 3.50 & 5 & 7.60 & 8.38 \\
\hline Male participants & 15 & 10.80 & 13.52 & 10 & 6.50 & 5.46 & 5 & 19.40 & 20.84 \\
\hline Top sport success & $\mathbf{N}$ & Mean & SD & $\mathbf{N}$ & Mean & SD & $\mathbf{N}$ & Mean & SD \\
\hline Relative total success (\%) & 16 & 11.53 & 19.44 & 11 & 9.04 & 20.43 & 5 & 17.00 & 17.89 \\
\hline Relative female success (\%) & 13 & 16.31 & 29.42 & 8 & 15.25 & 32.70 & 5 & 18.00 & 26.83 \\
\hline Relative male success $(\%)$ & 13 & 8.46 & 18.85 & 8 & 8.75 & 20.64 & 5 & 8.00 & 17.89 \\
\hline
\end{tabular}

This could explain why significant correlations were found in the female and male population separately. It is possible that a male focus on achievement leads to the higher male participation rates on an elite level (Fung, 1992). Other studies confirm that women with disabilities are underrepresented at disability sports (DePauw, 1994; Grimes \& French, 1986). However, gender differences in participation rates were not found to be significant in this study, which may be explained by the small sample sizes. It can be concluded that the supply function from mainstream sports to elite sports, and at the same time the inspirational function from elite sports to mainstream sports exist when dividing the analysing by gender.
Mainstream and elite sports participation rates were found to correlate significantly in team sports, but not in individual sports (figure $2 \mathrm{a}$ and $3 \mathrm{a}$ ). As mentioned by Van Bottenburg (2002) "elite sport does not automatically encourage sports participation. Doing leads to watching, but watching does not automatically lead to doing" (p. 20). The popularity of team sports among the general public is unquestionable (Mujika, 2007) whereas the popularity of individual athletes continues only as long as the performance remains exceptional (Schwartz, 1973). This might imply a more constant inspiring function of elite sport teams compared to individual elite athletes. However, for the male population a significant correlation of 
$\mathrm{r}=0.866(\mathrm{p}$ (one-tailed) < 0.05) was found between mainstream and elite participation in individual sports. This supports findings of Dickinson and Perkins (1985) who found that other athletes are more important in initial sports participation of male athletes than in that of females, who cited their mothers to be the primary introductory sports socialization agents. On the other hand the male focus on achievement (Fung, 1992) as mentioned earlier might influence the supply function of male mainstream participants to elite participants. From the results it can be concluded that the supply- and inspirational models not only depend on gender but also on the type of sports. Active talent recruitment seems therefore more necessary in order to create elite athletes in individual sports compared to team sports, especially in the female individual sports.

A significant correlation was shown between elite participation rate and achieved Paralympic success (figure 1a) when analysing all Paralympic sports. This correlation was comparable for both women and men (figure $1 \mathrm{~b}$ and $1 \mathrm{c}$ ). However, no significant correlation was found in individual sports in general and female individual sports (figure $2 \mathrm{a}$ and $2 \mathrm{~b}$ ). In team sports the correlation between elite participation rate and achieved elite sport success was strong $(\tau$ $=0.738(\mathrm{p}$ (one-tailed) $<0.05$, figure 3a). Since the amount of athletes in a team differs per team sport it is hard to draw conclusions out of this finding. The only conclusion which can be made is that for individual sports an increase in Paralympic success does not automatically lead to an increase in the amount of elite athletes and that the amount of elite athletes is not an accurate parameter to predict relative Paralympic success. This can be explained by the different possibilities of being successful in the various individual sports due to different classification systems. Individual athletes can even be successful in different disciplines of their sport. To be able to compare team sports with individual sports we chose to use relative success. An additional analysis on absolute success showed no significant relationships between elite participation rate and absolute Paralympic success in all Paralympic sports and in the team sports. However, in the individual sports a significant correlation of $\tau$ $=0.486(\mathrm{p}$ (one-tailed) < 0.05) was found between absolute elite sport success and elite participation rates. This shows that the different possibilities of being successful influence the results. It is clear that there is a need for a more accurate measurement of success which allows researchers to compare team sports and individual sports.

A significant correlation between mainstream participation rates and achieved Paralympic success was found when analysing all Paralympic sports $(\tau=0.478, \mathrm{p}$ (one-tailed) $<0.05$, figure 1a). This means that certain amounts of mainstream participants 'produce' Paralympic successful athletes and / or that Paralympic success and accompanying role models encourage people with a disability to take up some sports discipline. For team sports and individual sports separately no significant correlation was found, neither for the situation of only women or men. The results support many other studies in able-bodied sports concluding that the effect of role models seems to differ between sports (Van Bottenburg, 2002; Van Bottenburg, 2003; De Knop et al., 2006). It may be concluded that a Paralympic champion inspires people with a disability to be more active, although not necessarily with the same gender. This reasoning can be explained by findings of Grimes (1988) reporting that the number of male disability sports role models continues to grow more compared to female role models as a result of greater numbers of male athletes participating in sports. Therefore, women with disabilities are more likely than males to have crossgender athletic role-models (Grimes 1988), which is also shown in able-bodied sports (Giuliano, Turner, Lundquist \& Knight, 2007).

In able-bodied sports a significant correlation of $r=0.535(p<0.01)$ was shown between percentages of athletes participating in an organised way and the amount of medals per million inhabitants during the 
Olympic games of the period 1992-2000 (Van Bottenburg, 2002). In this study a correlation of $\tau=0.478$ ( $p$ (one-tailed) < 0.05 ) was found between mainstream participation rates and Paralympic success. Since longitudinal and cross-sectional data were mixed in the analysis on able-bodied sports and another measurement of success was used, a comparison between able-bodied sports and sports for people with a disability cannot be reliably made. Therefore, it is necessary to pay particular attention to differences in the 'double pyramid theory' between disability sports and able-bodied sports. It might even be that the two models are cross-linked in a way that able-bodied athletes inspire people with a disability to take up some sports discipline.

\section{Limitations}

While this was a descriptive study designed to collect information about the relationships between participation rates and Paralympic success in disability sports, there were aspects that were not totally explored. Female and male participation rates on a mainstream level were not reported by every sports federation, since they do not collect this type of information about their participants. Therefore, smaller sample sizes had to be used in some tests, which influences the results.

This study was limited to only the situation of disability sports in the Netherlands. This country was chosen because Dutch athletes are active in almost all Paralympic summer sports and are relatively successful. Furthermore, the organisation of disability sports in the Netherlands is very innovative. However, sample sizes would have been larger when focussing on different countries. That approach would have given the opportunity to analyse differences between every single Paralympic sport and not only between individual- and team sports. The distinction used in this study was limited by the diversity of the different sports. For example, some individual sports do have disciplines for duos and every team sport is practised by different amounts of athletes. By using relative success instead of absolute success, part of this problem was solved. However, there is a great need for a more accurate measurement of success which allows researchers to compare team sports and individual sports.

\section{CONCLUSIONS AND PERSPECTIVES}

Currently, knowledge in the area of relationships between participation rates and elite sport success in disability sports is limited. This study showed that a two-way relationship is partly present in disability sports; on the one hand there is a supply function from mainstream sports to elite sports, and on the other hand there is an inspirational function from elite sports to mainstream sports. However, these correlations were different for females and males and for team sports and individual sports. In order to make good policy, there is still great need to further determine relationships between participation rates and achieved success within a certain sport and within special populations. A broad international study may be an accurate way to investigate this. It is advisable to analyse relationships in able-bodied sports and disability sports in the same study since they might even be cross-linked.

\section{REFERENCES}

Arthur, S. \& Finch, H (1999). Physical activity in our lives: qualitative research among disabled people. Health Education Authority. London.

Bosscher, V. de, Knop, P. de, Bottenburg, M. van \& Shibli, S. (2006). A conceptual framework for analysing Sports Policy Factors Leading to international sporting success. European Sport Management Quarterly, 6 (2), 185-215.

Bottenburg, M. van (2002). Sport for all and elite sport: do they benefit one another? Paper for the IX World Sport for All Congress, Papendal, the Netherlands, 27-30 October.

Bottenburg, M. van (2003). Top- en breedtesport: een Siamese tweeling? In: K. 
Breedveld (red.), Rapportage Sport (285312). Den Haag, SCP.

Campen, C. van, Schellingerhout R (2005). 'Gezondheid en zorg'. In: De sociale staat van Nederland (129-153). Den Haag, SCP.

Cooper, R.A., Quatrano, L.A. \& Axelson, P.W. (1999). Research on physical activity and health among people with disabilities: a consensus statement. Journal of Rehabilitation Research and Development, 36 (2), 142-54.

DePauw, K (1994). A feminist perspective on sports and sports organizations for persons with disabilities. In: Steadward, R.D. et al. VISTA '93: the outlook (467-477). Edmonton, AB: Rick Hansen Centre.

DePauw, K. \& Gavron, S.J. (1995). Disability and sport. Champaign (IL), Human Kinetics

Dickinson, J. \& Perkins, D. (1985). Socialization into physical activity for the disabled populations. Canadian Association for Health, Physical Education, and Recreation, 51 (8), 4-12.

Doll-Tepper, G. (1999). Disability sport. In: Riordan, D. \& Krüger, A. The international politics of sport in the twentieth century (177-190). London, E \& FN Spon.

Durstine, J.L., Painter, P., Franklin, B.A., Morgan, D., Pitetti, K.H. \& Roberts, S.O. (2000). Physical activity for the chronically ill and disabled. Sports Medicine, 30, 207219.

Fung, L. (1992). Participation motives in competitive sport: A cross-cultural comparison. Adapted Physical Activity Quarterly, 9, 114-122.

Giuliano, T.A., Turner, K.L., Lundquist, J.C. \& Knight, J.L. (2007). Gender and the selection of public athletic role models. Journal of Sport Behavior, 30, 161-198.

Gold, J.R. \& Gold, M.M. (2007). Access for all: the rise of the Paralympic Games. The Journal of the Royal Society of the Promotion of Health, 127 (3), 133-141.

Grimes, P.S. (1988). Disabled women and girls in sport/competitive opportunities for disabled youth. Seventeenth National Conference: "Bridges of Progress", 68-70.

Grimes, P.S. \& French, L. (1986). Barriers to disabled women's participation in sports.
Journal of Physical Education, Recreation, and Dance, 58 (3), 24-27.

Heath, G.W. \& Fentem, P.H. (1997). Physical activity among persons with disabilities: a public health perspective. Exercise and Sport Sciences Review, 25, 195-234.

Knop, P. de, Bosscher, V. de, Bottenburg, M. van \& Leblicq, S. (2006). 'Topsport in Vlaanderen en Nederland: een wereld van verschil'. In: Paul De Knop, Jeroen Scheerder \& Bart Vanreusel, Sportsociologie. Het spel en de spelers (201-214). Maarssen, Elsevier gezondheidszorg.

Kooiker, S. \& Campen, C. van (2006). 'Vrijetijdsbesteding'. In: Jeugd met beperkingen. Rapportage gehandicapten (99-123). Den Haag, SCP.

Lindert, C. van, Jong, M. de \& Dool, R. van den (2008). (On)beberkt sportief. Monitor sportdeelname van mensen met een handicap 2008. Den Haag, DeltaHage.

Linenger, J.M., Chesson, C.V. \& Nice, D.S. (1991). Physical fitness gains following simple environmental change. American Journal of Preventive Medicine, 7, 298-310.

Liow, D.K. \& Hopkins, G. (1996). Training practices of athletes with disabilities. Adapted physical Activity Quarterly, 13, 372-381.

Mujika, I (2007). Challenges of team-sport research. International Journal of Sports Physiology and Performance, 2, 221-222.

Ploeg, H.P. van der, Beek, A.J. van der, Woude, L.H.V. van der \& Mechelen, W. van (2004). Physical activity for people with a disability: a conceptual model. Sports Medicine, 34 (10), 639-649.

Roberts, K., Dench, S., Minten, J. \& York, C. (1989). Community response to leisure centre provision in Belfast. London, UK: Sports Council for Northern Ireland.

Shephard, R.J. (1991). Benefits of sport and physical activity for the disabled: implications for the individual and for society. Scandinavian Journal of Rehabilitation Medicine, 23 (2), 51-9.

Sherrill, C. \& Williams, T. (1996). Disability and sport: Psychosocial perspectives on 
inclusion, integration and participation. Sports Science Review, 5, 42-64.

Steadward, R.D. \& Wheeler, G.D. (1996). The young athlete with a motor disability. In: Bar-OR, O. (Ed.), The child and adolescent athlete (493-520). Oxford, Blackwell.

Swanson, S.R., Colwell, T. \& Zhao, Y. (2008). Motives for participation and importance of social support for athletes with physical disabilities. Journal of Clinical Sports Psychology, 2, 317-336.

Schwartz, J.M. (1973). Causes and effects of spectator sports. International Review for the Sociology of Sport, 8, 25-45.

Vanlandewijck, Y., Biesen, D. van, Verellen, J., Reynders, S., Meyer, C., Vliet, P. van de. (2007). Socio-economic determinants of
Paralympic success. The Sobama Journal, $12,16-22$.

VWS (2005). Toekomstig sportbeleid; Nota Tijd voor sport, bewegen, meedoen, presteren. Minesterie van Volksgezondheid, Welzijn en Sport. Den Haag, Sdu.

VWS (2008). The power of sport. Ministry of Health, Welfare and Sport. Den Haag, Sdu.

Wheeler, G.D., Steadward, R.D., Legg, D., Hutzler, Y., Campbell, E., \& Johnson, A. (1999). Personal investment in disability sport careers: An international study. Adapted physical Activity Quarterly, 16 (3), 238-250.

Corresponding author's e-mail address: rinske.dejong@noc-nsf.no

\section{RELATIONEN ZWISCHEN DEN TEILNAHME RATEN IM BREITENSPORT UND ERFOLGEN IM ELITE-SPORT IN BEHINDERTENSPORTARTEN}

(Resümee)

Die Absicht dieser Studie war es, Beziehungen festzustellen zwischen den Teilnahmeraten im Breiten- und Elitesport von Personen mit Behinderung und den erreichten Erfolgen im Elitesport. Es wurden Daten über die Leistungen von holländischen Sportlern in 16 Sommersportarten der Paralympics 2008, in denen die Niederlande aktiv waren, und über die Breitensport- Teilnahme in diesen Sportarten mithilfe von Fragebögen und zusätzlichen Interviews gesammelt. SpearmanKorrelation oder Kendall-Tau wurden zur Analyse der Korrelationen in allen paralympischen Sportarten angewendet - separat in Team- und Individualsportarten - mit Korrekturen für Geschlechtsunterschiede. Es kann bestätigt werden, dass teilweise eine wechselseitige Beziehung im Behindertensport besteht; einerseits gibt es eine Zulieferfunktion von Seiten des Breitensports Richtung Elitesport, andererseits besteht auch eine inspirierende Funktion vom Elite- zum Breitensport. Allerdings waren diese Korrelationen unterschiedlich zwischen Frauen und Männern und zwischen Team- und Individualsportarten. Diese Ergebnisse scheinen relevant zu sein hinsichtlich der Maßnahmen für einen Anstieg der Teilnahmeraten im Behindertensport auf Breitensportebene sowie bezüglich der Verbesserung der Erfolge bei paralympischen Spielen.

SCHLÜSSELWÖRTER: Teilnahmeraten, Breitensport, Erfolge im Elitesport, Behindertensport, Doppelpyramidentheorie, Sportpolitik, Paralympics. 


\section{RELATION ENTRE LE TAUX DE PARTICIPATION TRADITIONNEL ET LE SUCCES DES SPORTS D'ELITES DANS LE HANDISPORT \\ (Résumé)}

L'objectif de cette étude était de déterminer la relation entre le taux de participation traditionnel et celui des sports d'élites dans le domaine du handisport et l'accomplissement du succès du sport d'élite. Les données d'athlètes élites Hollandais présents dans les 16 disciplines représentées aux Jeux Paralympiques d'été de 2008 et celles d'athlètes récréatifs des mêmes disciplines sportives ont été collectées à l'aide de questionnaires et d'entretiens. Les indices de corrélation de Spearman et de Kendall ont été utilisés pour analyser les relations dans tous les sports Paralympiques puis dans les sports individuels et d'équipes séparément, en corrigeant pour la différence des genres. Il peut être conclu qu'il existe une relation a deux sens, d'une part il y a une fonction d'approvisionnement du sport récréatif vers le sport élite et d'autre part il y a une fonction d'inspiration du sport élite pour les récréants. Cependant ces relations diffèrent selon le genre, hommes ou femmes, et selon le type de sports, individuel ou d'équipe. Ces résultats confirment la nécessité de développer une politique de développement du handisport au niveau récréatif pour augmenter le taux de participation et favorable au succès du mouvement Paralympique.

MOTS CLEFS: Taux de participation, sports récréatifs, sports élites, handisport, théorie de la double pyramide, politique sportive, mouvement Paralympique. 